\title{
Banking Competition and Firm-Level Financial \\ Constraints in Latin America
}

\author{
Autores: \\ Roberto Álvarez \\ Mauricio Jara
}




\title{
Banking Competition and Firm-Level Financial Constraints in Latin America*
}

\author{
Roberto Álvarez** \\ Mauricio Jara ${ }^{* * *}$
}

\begin{abstract}
Prior literature argues that, given the existence of information asymmetries and agency costs, higher competition may increase financial constraints by reducing banks' incentives to build lending relationships. Using a sample of listed firms for six Latin American countries, we analyze the relation between banking competition and financial constraints. We find evidence in line with prior research that banking competition increases financial constraints. This result is robust and heterogeneous. We include other country-specific variables and check the robustness of our findings; the main results hold. Our results show that the effect of competition differs across firms and industries. Specifically, consistent with the information hypothesis, the negative impact of competition is higher for small quoted firms and for lowassets tangibility industries. Also, as expected, we find evidence that firms are more affected by financial constraints during the last crisis. This negative effect is larger for firms in more competitive banking industries.
\end{abstract}

Keywords: Financial Constraints, Emerging Markets, Latin America, Banking, Asset Tangibility JEL codes: C20, G00, G20 and G30

\footnotetext{
* Jara thanks Fondecyt Initiation Project No. 11110021 for funding. We thank Rodrigo Wagner, Francisco Marcet, Félix López, and Pablo San Martín as well as seminar attendants at School of Economy at Business at the Universidad de Chile and Annual Meeting 2015 of the Sociedad de Economía de Chile (SECHI) for their valuable comments and suggestions.

${ }^{*}$ School of Economics and Business, Universidad de Chile, Chile; Email: robalvar@fen.uchile.cl

${ }^{* * *}$ Corresponding author, School of Economics and Business, Universidad de Chile, Chile; Email: mjarab@fen.uchile.cl
} 


\section{Introduction}

Prior literature has widely debated the relation between banking competition and credit access. Theoretically, higher competition has an ambiguous impact on firm financing. On the one hand, the market power hypothesis suggests that, by reducing interest rates, higher competition facilitates credit access or relaxes financial constraints. On the other hand, the information hypothesis argues that, given the existence of information asymmetries and agency costs, higher competition increases financial constraints by reducing banks' incentives to build lending relationships (Petersen \& Rajan 1995). Also, fierce competition may relax the quality of screening (Broecker 1990; Marquez 2002) and reduce investments in information acquisition technologies (Hauswald \& Marquez 2003, 2006).

The empirical literature has not yet settled this debate, and the evidence is, in general, mixed. Recent evidence by Ratti et al. (2008) for European countries find that higher banking concentration, which serves as a proxy for competition, is associated with reduced financial constraints. In contrast, Ryan et al. (2014), using the same method for a large sample of SME European firms shows strong support consistent with the market power hypothesis that lower competition increases financial constraints.. ${ }^{1}$

Two other recent studies also favor the market power hypothesis. Leon (2015) examines a large sample of firms from 69 developing and emerging countries and three indicators of banking competition and finds evidence that competition alleviates credit constraints. Also, Love and Martinez-Peria (2015) find evidence that competition increases access to finance in a sample of firms from 53 countries. Both Leon and Love and Martinez-Peria show that banking concentration

\footnotetext{
${ }^{1}$ Some prior studies use the introduction of regulations in the United States to look at the impact of a more competitive banking industry on several dimensions of credit access. These results are also mixed. See, for example, Zarutskie (2006) and Rice and Strahan (2010) for contrasting empirical evidence.
} 
is not a good measure of banking competition. Instead, direct measures of banking competition provide less ambiguous findings about the relation between competitive markets and financial constraints.

We contribute to this literature in two ways. First, we provide new evidence for a sample of Latin American countries. Second, we look at potential heterogeneous effects by firm size, industry financing needs, and the onset of financial crises. The question of banking competition's effect on credit access is very relevant not only due to the ambiguous theoretical predictions but also because it has important policy implications. Prior literature shows that credit access is important along several dimensions including productivity (Ibarrarán et al. 2009; Crespi et al. 2014), firm creation and growth (Aghion et al. 2007), innovation (Savignac 2008), and entry and survival in export markets (Berman \& Héricourt 2010; Jaud \& Kukenova 2011; Manova 2013), among others.

Our results are in line with the information hypothesis. We find that banking competition increases financial constraints. This result is robust and heterogeneous. We include other countryspecific financing variables and check the robustness of our findings; the main results hold. We also find that, as expected, the negative relation differs across firms and industries. Consistent with the information hypothesis, the negative impact of competition is higher for small listed firms and for low-assets tangibility industries. Compared to previous studies (Love and Martinez-Peria, 2015 and Leon, 2015) focusing on small firms, our sample is constituted by listed firms. These listed firms have access to external funds, but may be partially constrained. Then, we interpret our findings as negative effects of competition along the intensive margin rather than the extensive margin as the other previous studies do. 
The remainder of this paper is organized as follows. Section 2 describes the data set. Section 3 discusses the method. Section 4 presents the results and several robustness checks. Finally, Section 5 concludes.

\section{Data Sources}

Our data set comprises firm-level information from Thomson Reuters One and S\&P Compustat Global Advantage and country-level data from the World Bank. Our raw data sample consists of 593 firms and 7,239 observations of annual financial information from 1999 to 2013 . Because we focus only on nonfinancial firms, following Ratti et al. (2008), we exclude all firms with a SIC over 6000. We also eliminate firms with less than three years coverage and firms with missing values for capital expenditures, sales, assets, debt, cash flow, and stock prices. Following Ratti et $a l$. and Love (2003), we also exclude observations with ratios of investment to assets above 2.0 and sales to assets above 4.5. Finally, we merge the financial data from Compustat Global with ownership data obtained from Thomson One and drop outliers in the top and bottom 1\% of each variable. The final sample is an unbalanced panel of 3,181 observations from 445 quoted nonfinancial firms from Argentina, Brazil, Chile, Colombia, Mexico, and Peru. Table 1 provides the definition of each variable considered in the empirical analysis. Table 2 provides a further description of the sample by country. The largest (smallest) sample country corresponds to Chile (Colombia) with 1,006 (92) observations. Table 3 presents the correlation matrix for all variables included in the estimations.

[TABLE 1 ABOUT HERE]

[TABLE 2 ABOUT HERE]

[TABLE 3 ABOUT HERE] 
Table 1 shows that the interest variables such as investment, cash flow, and leverage are all defined in the standard way, scaled up by total assets. The measure of banking competition is defined as the Boone index and comes from the World Bank. This index is calculated as the elasticity of profits to marginal costs. To estimate this elasticity, the log of a measure of profits is regressed against a log measure of marginal costs. The main idea of this indicator is that more efficient banks achieve higher profits (Boone 2008). The more negative the Boone indicator is, the higher the level of competition in the market becomes because the effect of reallocation increases. However, we use the inverse value of Boone index in order to make easy interpretation of our results (higher inverse Boone Index means higher competition).

The Boone index is calculated at the country level and does not consider, for example, withincountry regional differences in banking competition. This limitation can be very problematic in some large countries such as Brazil and Mexico, where regional disparities can generate differences in banking competition. However, given the sample of quoted firms, the relevant measure is plausibly the aggregate index because large and quoted firms relate with large and main banks in the country. Also, if this measure is not relevant, it would work against our hypothesis that banking competition has an effect on financial constraints. We have also used a measure of banking concentration to compare our results with this traditional proxy of competition. This variable is measured as the five-bank assets concentration and is calculated with information from Bankscope.

Table 2 shows that the sample average investment over assets is about $7 \%$, with lower values for Argentina (5.2\%) and higher values for Brazil (8.0\%). The sample average of cash flow over assets is $10.5 \%$, with higher values for Peru (14.1\%) and lower values for Argentina (8.3\%). The 
sample average is about $25 \%$. Indebtedness is relatively higher for Brazilian firms and lower for Colombian firms than the sample average.

The descriptive statistics for banking competition indicates that the Boone index, an inverse value, is 0.074. According to the index, the most and the lowest competitive industries are in Brazil (0.163) and Mexico (0.027), respectively. In terms of concentration, the five largest banks explain, on average, about $72 \%$ of total assets. The most concentrated banking industry is Peru (90.3\%), and the least concentrated is Argentina (55.0\%).

The data set presents two main concerns. First, because we use information for quoted firms, they are larger than the average firm in the economy. These firms may be less suitable to study this topic. However, even though these firms are comparatively large within these countries, they are smaller than average firms in developed countries. The average size (in total assets) of firms in our sample is about US\$800 million, much lower than the average of more than US $\$ 3,200$ million in the sample of European countries used by Ratti et al. (2008). In addition, although listed firms have access to external funds (banking loans or bonds), they may be partially constrained. Then, compared to previous works using small firms in developing countries (Love and Martínez.Peria, 2015; Leon, 2015), we argue that those studies focus on extensive margin (i.e., percentage of firms obtaining external funds) whereas we concentrate on the intensive margin (i.e., extent of financial constraints). Finally, if large firms in these countries are not financially constrained, this condition works against our hypothesis.

Second, given the small number of firms in the sample, a concern arises about the representativeness of these firms compared with the population. Because we use information for quoted firms, our sample is clearly not representative of the population. These firms are larger and have better access to financial markets than firms in the population. Thus, we are careful not to 
discuss findings and implications as they are applicable to the average firm in developing countries. As we show later in our results, showing that relevant differences exist in financial constraints according to size is indeed a useful exercise. Obviously, these financial constraints may be larger for small firms in these Latin American countries.

\section{Methodology}

The model is based on the investment-cash flow sensitivity specification of Fazzari et al. (1988). The model assumes the existence of a wedge in financing costs between internal and external sources of funds. Hence, the higher the wedge of funding costs is, the more financially constrained firms are and the more dependent they are on internal cash flow to satisfy their investment opportunities. Therefore, dependence on internal funds can lead firms to invest suboptimally.

Kaplan and Zingales (1997) cast doubts on the usefulness of investment-cash flow sensitivity regressions in Fazzari et al.'s (1988) methodology. Instead, they use dividend payments to identify a financially constrained subsample. In contradiction with Fazzari et al., they find no monotonically positive relation between investment and cash flow. Specifically, they find that the subsample of distressed firms have lower levels of investment-cash flow sensitivity and conclude that this coefficient is not a good proxy for financial constraints. This finding opened a strong and as yet unconcluded debate regarding the usefulness of some metrics for capturing financial constraints (Cleary 1999; Fazzari et al. 2000; Kaplan \& Zingales 2000; Huang 2002; Allayannis \& Mozumdar 2004; Cleary et al. 2007; Lyandres 2007; Hadlock \& Pierce 2010). However, the investment-cash flow sensitivity specification has been widely used in corporate finance literature (Pindado et al. 2011).

To capture the specific differential effect of banking industry characteristics on the investment-cash flow sensitivity coefficient, the cash flow variable is interacted with measures of 
banking competition. This interaction term is the main variable of interest because it captures whether higher competition relaxes or increases financial constraints.

As in Laeven (2003) and Ratti et al. (2008), the maximization conditions of the Euler equation is used to derivate a model for investment including the lagged investment variable for capturing the dynamics (Aivazian et al. 2005). The empirical model is

$$
\operatorname{Inv}_{i, t}=\beta_{1} \operatorname{Inv}_{i, t-1}+\beta_{2} \operatorname{Cashflow}_{i, t}+\beta_{3} \operatorname{Cashflow}_{i, t} * \operatorname{Comp}_{c, t}+C V_{i, t}+f_{i}+y c_{t}+u_{i, t}
$$

where Inv $v_{i t}$ is the capital investment of firm $i$ in year $t$; Cash Flow $i t$ is the cash flow of firm $i$ in year $t$; $C o m p p_{c, t}$ measures the level of competition of the banking industry; and $C V_{i, t}$ is a set of control variables as defined in Table 1. In addition, a set of fixed effects is included at different aggregation levels to control for unobservable time-invariant and time-variant fixed effects. In particular, fixed effects are included at the firm level $\left(f_{i}\right)$ and country-year level $\left(y_{c t}\right)$.

As previously mentioned, in line with prior literature cash flow $\left(\beta_{2}\right)$ is expected to be positive. In the presence of financial constraints, an increase in cash flow should increase investment. More important, because the hypothesis states that banking industry competition potentially affects financial constraints, an interaction variable is introduced between cash flow and the indicator of banking competition. In the baseline regressions, the Boone indicator (Boone) is used as measure of competition.

There are two main competing hypotheses about the relation between banking competition and financial constraints. The more traditional view argues that higher competition reduces interest rates and improves firms' access to credit. As such, competition relaxes financial constraints, and thus investment would be less sensitive to cash flows in more competitive markets. In this case, $\beta_{3}$ 
would be negative. ${ }^{2}$ In contrast, some studies that focus on informational problems suggest that financial constraints are higher in more competitive banking industries. According to this argument, due to the existence of information asymmetries and agency costs, higher competition increases financial constraints by reducing banks' incentives to build lending relationships (Petersen \& Rajan 1995). The impact is more negative for small and new firms because they are more opaque and have less credit history than large and older firms (Rice \& Strahan 2010; Ryan et al. 2014). Also, fiercer competition may relax the quality of screening (Broecker 1990; Marquez 2002) and reduce investments in information acquisition technologies (Hauswald \& Marquez 2003, 2006). Thus, competition can increase financial constraints. In this case, $\beta_{3}$ would be positive.

In sum, in line with Hypothesis $1, \beta_{3}$ is positive (negative) if industry banking competition increases (mitigates) financial constraints. This approach is similar to Ryan et al. (2014) who uses the Lerner index to measure competition and finds evidence of a mitigating effect of banking competition on financial constraints for European firms. To compare our findings with previous evidence, we also use a measure of banking concentration (Bankcon).

The information on firms of different countries over time contained in our panel database captures the potential effect of other country-specific and time-varying banking industry features such as financial market development. In fact, the competition variable reflects differences in financial development that also affect credit access. The introduction of additional interactions between cash flow and these variables better isolates the impact of banking competition on financial constraints.

\footnotetext{
2 The Boone Index should be negative because it measures the relation between profits and marginal cost. However, for ease of interpretation, in all our regressions we introduce the inverse value of the Boone. Thus, a higher value of Boone indicates more competition.
} 
Due to endogeneity problems in dynamic panel data, ordinary least squares estimators can provide coefficients that are biased. Thus, Blundell and Bond's (1998) generalized method of moments (GMM) system estimator is used. The GMM system estimator deals with the endogeneity issues in the relation between investment and cash, among others. In general, all of the right-hand variables are potentially endogenous (Pindado et al. 2011). As equation (1) shows, even though all these variables are exogenous, the introduction of a lagged explanatory variable introduces endogeneity. The GMM system estimator presents some advantages over others dynamic panel models that are regularly used in corporate finance research (Flannery \& Hankins 2013).

The consistency of the estimates depends critically on the absence of second-order serial autocorrelation in the residuals and on the validity of the instruments (Arellano \& Bond 1991). Accordingly, $p$-values of the first and second order autocorrelation test are reported. To test the validity of the instruments, the Hansen test of overidentifying constraints is used, which tests for the absence of correlation between the instruments and the error term and, therefore, checks the validity of the selected instruments.

\section{Econometric Results}

\subsection{Basic results}

The analysis begins by testing whether bank competition influences firms' financial constraints for the entire sample. Table 4 presents the results of the baseline estimations. Column 1 shows the results of the basic estimations using only Tobin's Q and a set of country-year dummies as control variables. Column 2 introduces additional firm characteristics as control variables. To deal with 
the problem of attrition, Column 3 considers only surviving firms, that is, only those that remain in the sample to $2013 .^{3}$

\section{[TABLE 4 ABOUT HERE]}

The evidence in Table 4 across specifications indicates that cash flow (Cashflow) is positively associated with investment. This evidence is consistent with the existence of financial constraints. The results are robust to the inclusion of additional covariates, including Tobin's Q, which controls for growth opportunities, and avoid confounding factors that can cause a spurious correlation between investment and cash flow. In Columns 1 and 2, the coefficient of Cashflow is positive $(0.038, t=1.97$ and $0.055, t=2.60$, respectively) and statistically significant at the $5 \%$ and $1 \%$ level, respectively. The evidence is similar for estimations in Column 3 that restricts the sample to surviving firms.

Considering Hypothesis 2 relative to the impact of banking competition, Columns 1 and 2 of Table 4 shows that the parameter for the interaction Cashflow $_{i, c, t} *$ Boone $_{c, t}$ is positive and statistically significant $(0.750, t=2.35$ and $0.805, t=2.54$, respectively). The quantitative relevance of competition is large. Using the estimation in Column (2), the marginal effect of cash flow on the investment ratio is $0.053+0.809 *$ Boone. Evaluated at the sample average of the Boones index (0.074), this result implies a marginal effect of 0.11 . If competition increases from the least competitive banking industry in the sample (Mexico, average Boone $=0.027$ ) to the most

\footnotetext{
${ }^{3}$ As indicated by Kaplan and Zingales (1997), the cash-investment sensitivity may be less pronounced for financially distressed firms. Then, based on Hadlock and Pierce (2010), we develop another attrition test by incorporating the WW index (Whited \& Wu 2006) of financial distress as a control variable of our model. In general, our results also hold.
} 
competitive (Brazil, Boone $=0.163$ ), the marginal effect increases from 0.07 to 0.18. Thus, our findings suggest that higher banking competition increases firms' financial constraints. These results support the informational hypothesis, which argues that higher competition reduces the incentives to gather information and to establish new lending relationships and therefore increases firms' financial constraints.

Methodologically, the GMM results pass the required tests of autocorrelation and instruments validity. As Table 4 shows, these tests do not reject either the null hypothesis of validity of the instruments (Hansen) or the null hypothesis of absence of second-order autocorrelation. ${ }^{4}$

Some prior studies, including Ratti et al. (2006), Ryan et al. (2014) and Love and MartinezPeria (2015), use the Lerner index and/or the banking concentration as a proxy of market power (an inverse measure of banking competition). However, we use the inverse Boone index for four main reasons. First, the Lerner index is not available for the entire period in Mexico. Second, as Leon (2015) points out, the Lerner index may not capture competition because the indicator is sensitive to the business activity reallocation to efficient firms, which is relevant in concentrated industries such as the Latin American banking sector. In addition, prior literature argues that pricecost margins are sensitive to efficiency and risk (Koetter et al. 2012). As a result, the Lerner index is not a clear inverse measure of competition because previous studies show that high competitive markets also have a higher Lerner index (Stiglitz 1989; Maudos \& Fernandez de Guevara 2004, 2007; Clerides et al. 2014). Third, Leuvensteijn (2008) suggests that the theoretical fundaments of the Lerner index are weak and the Boone index captures market competition directly. Four, as Ryan et al. (2014) points out, the use of banking concentration as a "structural" measure of market power could present some problems since it has been observed that banking

\footnotetext{
${ }^{4}$ These results hold for all GMM system estimations in the remaining tables.
} 
sector often are concentrated and competitive, or that the measure of concentration could proxy other market characteristics different than market power (average bank size, bank complexity, informational flow and the average market size). However, we have estimated the model using both measures - Lerner Index and Bank Concentration - in our baseline model and the main results hold ${ }^{5}$.

\subsection{Robustness Checks}

Table 5 provides a robustness check of the results of the interaction terms between cash flow and one measure of financial market development $(M \operatorname{kog} d p) .{ }^{6}$ If more developed financial markets are also more competitive, the banking competition variable may be capturing the effect of financial development and not higher competition. The results reveal a negative parameter for the interaction between cash flow and financial development for the three specifications (Columns 13), showing that higher financial development reduces financial constraints. However, these parameters are not statistically significant. In contrast, the interaction between cash flow and the Boone index is positive and significant. In general, after controlling for these additional variables, the findings are consistent with previous evidence that competition increases financial constraints.

\section{[TABLE 5 ABOUT HERE]}

If we replace the Boone index in equation (1) with a measure of banking concentration and we include also a measure of financial development, the results are similar to previous findings. The parameter for the interaction between cash flow and concentration is negative, suggesting that

\footnotetext{
${ }^{5}$ Results are available upon request.

${ }^{6}$ In this and the following regressions, we only show the results of the GMM estimations. For comparison, we show the ordinary least squares results of this main equation in the appendix. In general, the main results in terms of significance are similar for both methodologies. All other ordinary least squares results are available on request.
} 
banking concentration reduces financial constraints. The interactions with financial development are not statically significant ${ }^{7}$.

In sum, the results show that banking competition increases credit constraints in this sample of Latin American countries. These findings contrast with some prior literature such as Love and Martinez-Peria (2015) and Leon (2015). However, these previous studies focus on small firms operating in developing countries. This study thus adds to and complements to the literature by using information for listed firms from emerging countries. In fact, small firms may have no access to external finance (i.e., totally constrained). At the opposite end of the spectrum, listed firms have access to external funds (from banks or markets), but they may be partially constrained (i.e., level of funds obtained is smaller than the desired level of funds). In other words, compared to previous papers that focus on the extensive margin (number of firms obtaining external funds), this study concentrates on the intensive margin (size of financial constraints for firms with access to external finance).

\subsection{Heterogeneity Analysis}

The previous estimations estimate the average impact of cash flow on investment decisions. The evidence thus far suggests that financial constraints are relevant in Latin American countries and that these restrictions are more important in more competitive markets. However, these effects can be more fully investigated by exploiting the heterogeneous response of firms and industries to positive cash flows. In other words, the model now tests whether financial constraints are more relevant for some firms (industries) than others.

The following estimations are based on the prior corporate finance literature that shows that some firms are more prone to financial constrains than others (Fazzari et al. 1988; Almeida et al.

\footnotetext{
${ }^{7}$ These results are available open request.
} 
2004; Almeida \& Campello 2007; Hovakimian 2009; Lima-Crisóstomo et al. 2014). The literature that reports the investment-cash flow sensitivity relation has traditionally focused on the identification of restricted firms by using subsamples according to firms size (Devereux \& Schiantarelli 1990; Kadapakkam et al. 1998; Arslan et al. 2006), leverage (Whited 1992), dividends payout (Arslan et al. 2006), business groups affiliation (Hoshi et al. 1991; George et al. 2011), firm age (Oliner \& Rudebusch 1992), and assets tangibility (Almeida \& Campello 2007; Ratti et al. 2008). Although relevant differences on financial constraints may exist across firm age because younger firms are more likely to be excluded from financial markets (Brown et al. 2009), information of firm age is not available in this study's data set. Therefore, to shed some light on heterogeneity in financial constraints, two criteria are used to split the sample and provide separate regressions: firm size and industry asset tangibility.

The idea that financial constraints are more important for small firms and for those firms in industries with a lower proportion of tangible assets is tested. Both variables are related to the absence of collateral and greater opaqueness, which increase the information asymmetries in financial markets. Thus, banks are more reluctant to lend to these types of firms. Small firms are defined as those whose size (measured by assets) is lower than the median size of the corresponding country, industry, and year. Following Rajan and Zingales (1998), to explore how asset tangibility affects financial constraints, an exogenous measure of industry tangibility using information for the U.S. industries is also used. Industries with an indicator lower than the median across industries are defined as low tangibility industries. This last procedure is useful because it is an indicator of exposure that does not depend on banking competition or other industry characteristics of the country. 
Table 6 reports the results. In general, the findings are consistent with previous results and show that for both samples, divided by either assets tangibility or size, higher cash flow is associated with an increase in investment. To determine whether significant differences in financial constraints exist across firms and industries, the investment-cash flow parameter (marginal effect) is computed and whether statistical differences between both samples is determined. The marginal effect for firms in low- and high-tangibility industries is 0.166 and 0.093, respectively. According to the $t$-test, the difference is statistically significant. As expected, the evidence suggests that firms in low-assets tangibility industries are more financially constrained than firms in high-assets tangibility industries.

In the case of size, the results indicate significant differences between both groups of firms. The marginal effect of cash flow on investment is 0.140 and 0.029 for small and large firms, respectively. According to the $t$-test, the parameters difference is statistically significant, indicating that large firms are more financially constrained than small firms. In quantitative terms, the difference is relevant. Considering an increase of 1 standard deviation in cash flow (0.083) for small and large firms, the marginal effect implies an increase of $0.012(17 \%)$ and $0.002(3.5 \%)$, respectively, in the investment ratio of the average investment in the sample.

\section{[TABLE 6 ABOUT HERE]}

\subsection{Financial Crises}

Given that the sample period covers two recent international crises-the Asian crisis in 1999 and the global financial crisis of 2008-2009, this study investigates whether the financial crises affect financial constraints and whether the relation between financial constraints and competition changes during the crises. Prior corporate finance literature has raised the question about whether 
and, if so, how crises affect financial constraints (Almeida \& Campello 2007). ${ }^{8}$ For example, Campello et al. (2010), using a sample of 34 economies, show that during a financial crisis, CFOs tend to delay their investments or bypass attractive investments plans due to their inability to borrow externally. If banks tend to restrict credit during financial crises, financial constraints should be more important in these episodes. In addition, firms may to decide to postpone investment decisions due to lower demand. However, in this case, this factor should be controlled in part by some firm characteristics such as sales and Tobin's Q. Thus, in line with the first hypothesis, financial constraints should be amplified during the crises. To test this conjecture, an interaction is introduced between cash flow and a dummy for both crises. The parameter is expected to have a positive sign.

The second hypothesis under study is whether a more competitive banking industry increases or reduces financial constraints during a crisis. The conceptual foundation is very simple. Consider that as result of the financial crisis, banks need to decide whether allocate more or less credit to firms. We look at whether this depends on the degree of banking competition. It has been argued that banks with some monopoly power have more profits than competitive banks and therefore they have more to lose by taking more risk and lending in hard times (Matutes and Vives, 1996). In this case, we expect that more competition may help to alleviate financial constraints during a crisis. There also other arguments in the same direction. Competitive banks may be less restrictive during financial crisis because they could be forced by fierce competition to take more risk to get new clients and increase market share. Some literature related with this idea suggests that higher competition may reduce incentives for screening (Allen and Gale, 2004). However, in this case, it is not clear whether more competitive industries would be even less stringent during a crisis. It

\footnotetext{
${ }^{8}$ Both crisis episodes and financials constrains undermine an efficient firm's resource allocation and can lead to inefficient investment policies (Cleary 2002).
} 
has been also argued that higher competition may be associated with lower financial constraints whenever competitive pressures and adverse selection induces lending to potentially bad clients during a crisis (Broecker, 1990).

In contrast, considering that banks in non-competitive industries may concentrate their lending on few borrowers and they cannot afford a bankruptcy of these large clients, it can be argued that banks continue to finance these borrowers even when they have been adversely affected by the crisis and could be close to default. It is also possible that less competitive banks are more able to limit the detrimental consequences on lending during a crisis because, due to their market power, they have accumulated capital previously ${ }^{9}$. Then, in this case, lower competition would be associated with lower financial constraints during a crisis. For analyzing this issue, we introduce a triple interaction among cash flow, competition, and dummy for crisis. The parameter for this term is expected to be positive (negative) if higher competition increases (alleviates) financial constraints during episodes of financial crisis.

Table 7 presents the results of the basic regression with the introduction of the interaction between cash flow and competition and also the incorporation of the triple interaction that evaluates the impact of the financial crisis on the relation between banking competition and financial constraints. The table provides the results for two specifications. In the first column, the dummies for the financial crises for all countries are defined the same: 1999 in the case of the Asian crisis and 2008-2009 for the recent global financial crisis. In the second column, given that Argentina also had a crisis in the years following the Asian crisis, the dummy for this country includes 2000 and 2001.

\footnotetext{
${ }^{9}$ We thank an anonymous referee for suggesting us these two additional arguments.
} 


\section{[TABLE 7 ABOUT HERE]}

The main result from these estimations comes from the triple interaction, which is positive and statistically significant for the recent financial crisis only. This finding indicates that higher competition increases financial constraints during a crisis, which is not consistent with the notion that more competitive banks help to relax financial constraints during episodes of crisis. These results suggest that higher banking competition — at least in the last financial crises—did not help to channel more lending to firms. Finally, we calculate the marginal effects for crises and no crises periods. As expected, the results show that for both specifications financial constraints increases during a crisis, particularly in the most recent financial crisis. The marginal effect of cash flow on investment is positive and significant in non-crises years (about 0.10), and, as expected, it is higher during the recent financial crisis (about 0.14). The last row of the table shows that this difference is statistically significant.

\section{Conclusion}

Using firm-level information for six Latin American countries and a standard methodology, we explore the relation between banking competition and financial constraints. Several previous works examine this issue using different samples and measures of competition, and the evidence is, in general, not conclusive. We contribute to this literature by reporting the impact of banking competition for a sample of emerging markets, where financial constraints can be more stringent. This additional evidence is not only relevant due to the ambiguous theoretical predictions, but also because it has valuable implications for competition policy in emerging countries.

The debate on this literature has been dominated by the market power and the information hypotheses. We find evidence more in line with the information hypothesis. Our results indicate 
that banking competition increases financial constraints. This result is robust and heterogeneous. We check the robustness of this finding by including other country-specific financing variables, and the main results hold. We also find that, as expected, the negative relation differs across firms and industries. Consistent with the information hypothesis, the negative impact of competition is higher for small firms and low-tangibility industries.

Our results are not in line with some recent studies, including Love and Martinez-Peria (2015) and Leon (2015) who find that banking competition alleviates financial constraints. However, we believe that our paper complements this evidence. Compared to these previous papers that focus on small firms, we use information for listed firms. Unlike small firms, which have limited or no access to external finance, listed firms have access external funds but may be partially constrained. In other words, previous studies focus on the extensive margin whereas we concentrate our analysis on the intensive margin. That is, we concentrate our empirical analysis on the marginal effect of cash flow on investment; the previously cited works focus primarily on the dichotomous variables of credit access.

Our findings indicate that higher banking competition does not necessarily improve credit access in these countries and that financial constraints remain relevant, especially for the subset of small firms and more financially dependent industries. These results suggest that policies and instruments may be required to improve credit access in these countries. Also, these findings generate questions for additional research, in particular, on the real effects of financial constraints on other variables such as employment and productivity and on the effect of different corporate governance features that moderate the effect of bank competition on financial constraints. For instance, the existence of multiples large shareholders as a proxy of power distribution is an 
interesting topic as a moderating effect of the relation between investment cash flow sensitivity and banking competition. 


\section{References}

Aghion, P., Fally, T., Scarpeta, S., 2007. Credit constraints as barrier to the entry and post-entry growth of firms. Econ. Policy 22, 731-779.

Aivazian, V.A., Ge, Y., Qiu, J., 2005. Debt maturity structure and firm investment. Financ. Manage. 34, 107-119.

Allen, F., Gale, D., 2004. Competition and Financial Stability. J. of Mon., Cred. and Bank. 36, 3, 453-480.

Almeida, H., Campello, M., 2007. Financial constraints, asset tangibility, and corporate investment. Rev. Financ. Stud. 20, 1429-1460.

Almeida, H., Murillo, C., Weisbach, M.S., 2004. The cash flow sensitivity of cash. J. Financ. 59, 1777-1804.

Allayannis, G., Mozumdar, A., 2004. The impact of negative cash flow and influential observations on investment-cash flow sensitivity estimates. J. Bank. Financ. 28, 901-930.

Arellano, M., Bond, S., 1991. Some tests of specification for panel data: Monte Carlo evidence and an application to employment equations. Rev. Econ. Stud. 58, 277-297.

Arslan, O., Florackis, C., Ozkan, A., 2006. The role of cash holdings in reducing investment-cash flow sensitivity: Evidence from a financial crisis period in an emerging market. Emerg. Mark. Rev. 7, 320-338.

Berman, N., Héricourt, J., 2010. Financial factors and the margins of trade: Evidence from crosscountry firm-level data. J. Dev. Econ. 93, 206-217.

Blundell, R., Bond, S., 1998. Initial conditions and moment restrictions in dynamic panel data models. J. Econometrics 87, 115-143.

Boone, J., 2008. A new way to measure competition. Econ. J. 118, 1245-1261.

Broecker, T., 1990. Credit-worthiness tests and interbank competition. Econometrica 58, 429-452.

Brown, J.R., Fazzari, S.M., Petersen, B.C., 2009. Financing innovation and growth: Cash flow, external equity, and the 1990s R\&D boom. J. Financ. 64, 151-185.

Campello, M., Graham, J.R., Harvey, C.R., 2010. The real effects of financial constraints: Evidence from a financial crisis. J. Finan. Econ. 97, 470-487.

Cleary, S., 1999. The relationship between firm investment and financial status. J. Financ. 54, 673692. 
Cleary, S., 2002. International corporate investment and the role of financial constraints. Mecanografiado.

Cleary, S., Povel, P., M., R., 2007. The U-shaped investment curve: Theory and evidence. J. Finan. Quant. Anal. 42, 1-40.

Clerides, S., Delis, M.D., Kokas, S., 2014. A new data set on competition in national banking markets. http://ssrn.com/abstract=2448938.

Crespi, G., Fernández-Arias, E., Stein, E., 2014. Rethinking productive development: Sound policies and institutions for economic transformation. Palgrave Macmillan, Inter-American Development Bank.

Devereux, M., Schiantarelli, F., 1990. Investment, financial factors, and cash flow: Evidence from U.K. panel data. In R. Hubbard (Ed.), Asymmetric information, corporate finance and investment. University of Chicago Press. Chicago, 297-306.

Fazzari, S.M., Hubbard, R.G., Petersen, B.C., 1988. Financing constraints and corporate investment. Brooking Papers on Economic Activity 1, 141-195.

Fazzari, S.M., Hubbard, R.G., Petersen, B.C., 2000. Investment-cash flow sensitivities are useful: A comment on Kaplan and Zingales. Q. J. Econ. 115, 695-705.

Flannery, M.J., Hankins, K.W., 2013. Estimating dynamic panel models in corporate finance. J. Corp. Finan. 19, 1-19.

George, R., Kabir, R., Qian, J., 2011. Investment-cash flow sensitivity and financing constraints: New evidence from Indian business group firms. J. Multinatl. Financ. Manage. 21, 69-88.

Hadlock, C.J., Pierce, J.R., 2010. New evidence on measuring financial constraints: Moving beyond the KZ index. Rev. Financ. Stud. 23, 1909-1940.

Hauswald, R., Marquez, R., 2003. Information technology and financial services competition. Rev. Financ. Stud. 16, 921-948.

Hauswald, R., Marquez, R., 2006. Competition and strategic information acquisition in credit markets. Rev. Financ. Stud. 19, 967-1000.

Hoshi, T., Kashyap, A., Scharfstein, D., 1991. Corporate structure, liquidity and investment: Evidence from Japanese industrial groups. Q. J. Econ. 106, 33-60.

Hovakimian, G., 2009. Determinants of investment cash flow sensitivity. Financ. Manage. 48, $161-183$.

Huang, Z., 2002. Financial constraints and investment-cash flow sensitivity. Mecanografiado 
Ibarrarán, P., Maffioli, A., Stucchi, R., 2009. SME policy and firms' productivity in Latin America. IZA Discussion Papers No. 4486.

Jaud, M., Kukenova, M., 2011. Financial development and survival of African agri-food exports.

Kadapakkam, P.R., Kumar, P.C., Riddick, L.A., 1998. The impact of cash flows and firm size on investment: The international evidence. J. Bank. Financ. 22, 293-320.

Kaplan, S.N., Zingales, L., 1997. Do investment-cash flow sensitivities provide useful measures of financing constraints? Q. J. Econ. 112, 169-213.

Kaplan, S.N., Zingales, L., 2000. Investment-cash flow sensitivities are not valid measures of financing constraints. Q. J. Econ. 115, 707-712.

Koetter, M., Kolari, J., Spierdijk, L., 2012. Enjoying the quiet life under deregulation? Evidence from adjusted lerner indices for us banks. Rev. Econ. Stat. 94, 462-480.

Laeven, L., 2003. Does financial liberalization reduce financing constraints? Financ. Manage. 32, $5-34$.

Leon, F., 2015. Bank competition and credit constraints in developing countries: New evidence. J. Bank. Financ. 57, 130-142.

Leuvensteijn, M., 2008. The Boone-indicator: Identifying different regimes of competition for the American Sugar Refining Company 1890-1914. Discussion Paper Series 08-37, p. 37. Utrecht School of Economics.

Lima-Crisóstomo, V., López-Iturriaga, F.J., Vallelado-González, E., 2014. Nonfinancial companies as large shareholders alleviate financial constraints of Brazilian firm. Emerg. Mark. Rev. 18, 62-77.

Love, I., 2003. Financial development and financing constraints: International evidence from the structural investment model. Rev. Financ. Stud. 16, 765-791.

Love, I., Martinez-Peria, M., 2015. How bank competition affects firms'access to finance. World Bank Econ. Rev. 29, 413-338.

Lyandres, E., 2007. Costly external financing, investment timing, and investment-cash flow sensitivity. J. Corp. Financ. 13, 959-980.

Manova, K., 2013. Credit constraints, heterogeneous firms, and international trade. Rev. Econ. Stud. 80, 711-744.

Marquez, R., 2002. Competition, adverse selection, and information dispersion in the banking industry. Rev. Financ. Stud. 15, 901-926. 
Maudos, J., Fernandez de Guevara, J., 2004. Factors explaining the interest margin in the banking sectors of the European Union. J. .Bank. Financ. 28, 2259-2281.

Maudos, J., Fernandez de Guevara, J., 2007. The cost of market power in banking: Social welfare loss vs. cost inefficiency. J. .Bank. Financ. 31, 2013-2125.

Oliner, S.D., Rudebusch, G.D., 1992. Sources of the financing hierarchy for business investment. Rev. of Econ. Stat. 74, 643-654.

Petersen, M.A., Rajan, R.G., 1995. The effect of credit market competition on lending relationships. Q. J. Econ. 110, 407-43.

Pindado, J., Requejo, I., de la Torre, C., 2011. Family control and investment-cash flow sensitivity: Empirical evidence from the Euro zone. J. Corp. Financ. 17, 1389-1409.

Ratti, R., Lee, S., Seol, Y., 2008. Bank concentration and financial constraints on firm-level investment in Europe. J. .Bank. Financ. 32, 2684-2694.

Rice, T., Strahan, P., 2010. Does credit competition affect small-firm finance? J. Financ. 65, 861889.

Ryan, R., O'Toole, C., McCann, F., 2014. Does bank market power affect SME financing constrains? J. .Bank. Financ. 49, 495-505.

Savignac, F., 2008. Impact of financial constraints on innovation: What can be learned from a direct measure? Econ. Innov. New Technol. 17, 553-569.

Stiglitz, J.E., 1989. Markets, market failures, and development. Am. Econ. Rev. 79, 197-203.

Whited, T.M., 1992. Debt, liquidity constraints, and corporate investment: Evidence from panel data. J. Financ. 47, 1425-1460.

Whited, T.M., Wu, G., 2006. Financial constraints risk. Rev. Financ. Stud. 19, 531-559. 


\section{Appendix: Ordinary Least Squares Fixed Data Panel Regressions}

$\underline{\text { Table A1. Bank Competition and the Financial Constraints }}$

\begin{tabular}{|c|c|c|c|}
\hline Variables & $\begin{array}{c}(1) \\
\text { Total }\end{array}$ & $\begin{array}{c}(2) \\
\text { Total }\end{array}$ & $\begin{array}{c}\text { (3) } \\
\text { Surviving Firms }\end{array}$ \\
\hline$\overline{I n v_{i, t-1}}$ & $0.201^{* * *}$ & $0.191^{* * *}$ & $0.234^{* * * *}$ \\
\hline & $(3.436)$ & (3.151) & $(3.155)$ \\
\hline Cashflow $_{i, t}$ & $\begin{array}{l}0.061^{* * *} \\
(2753)\end{array}$ & $\begin{array}{l}0.071^{* * *} \\
(3.457)\end{array}$ & $\begin{array}{l}0.069^{* * *} \\
(3.006)\end{array}$ \\
\hline Cashflow $_{i, c, t} *$ Boone $_{c, t}$ & $\begin{array}{l}0.727^{* *} \\
(2.314)\end{array}$ & $\begin{array}{l}0.785^{* * *} \\
(2.698)\end{array}$ & $\begin{array}{l}0.753^{* * *} \\
(2.204)\end{array}$ \\
\hline Qtob & $\begin{array}{l}0.006^{* *} \\
(2.185)\end{array}$ & $\begin{array}{l}0.008^{* *} \\
(2.615)\end{array}$ & $\begin{array}{l}0.008^{* *} \\
(2.395)\end{array}$ \\
\hline P1 & & $\begin{array}{c}0.008 \\
(0.969)\end{array}$ & $\begin{array}{c}0.010 \\
(1.171)\end{array}$ \\
\hline Size & & $\begin{array}{c}-0.000 \\
(-0.126)\end{array}$ & $\begin{array}{c}0.000 \\
(0.053)\end{array}$ \\
\hline Lev & & $\begin{array}{l}-0.012 \\
(-1.096)\end{array}$ & $\begin{array}{l}-0.016 \\
(-1.376)\end{array}$ \\
\hline Longdebt & & $\begin{array}{c}0.005 \\
(1.409)\end{array}$ & $\begin{array}{c}0.005 \\
(1.478)\end{array}$ \\
\hline Cash & & $\begin{array}{l}-0.035 \\
(-1.504)\end{array}$ & $\begin{array}{l}-0.029 \\
(-1.227)\end{array}$ \\
\hline Sales & & $\begin{array}{l}-0.025^{* * *} \\
(-2.002)\end{array}$ & $\begin{array}{l}-0.023^{*} \\
(-1.815)\end{array}$ \\
\hline Observations & 2,982 & 2,982 & 2,587 \\
\hline$R$-squared & 0.191 & 0.199 & 0.219 \\
\hline Number of ID & 423 & 423 & 335 \\
\hline Country-Year FE & Yes & Yes & Yes \\
\hline Marg. effects & $\begin{array}{l}0.114^{* * *} \\
(7.15)\end{array}$ & $\begin{array}{l}0.129^{* * *} \\
(9.21)\end{array}$ & $\begin{array}{l}0.124^{* * *} \\
(7.90)\end{array}$ \\
\hline
\end{tabular}

Notes: $\operatorname{In} v_{i, t}$ is capital expenditures scaled by lagged total assets. Cashflow $w_{i, t}$ is the income-based cash flow over lagged total assets. Boone $c_{c, t}$ represents the Boone indicator as a proxy of bank competition. Qtob, P1, Size, Lev, Longdebt, Cash and sales are control variables defined in Table 1. $f_{i}$ is the firm-specific effect, $y c_{t}$ denotes the yearcountry dummies, and $u_{i, t}$ represents the individual error term. $t$-statistics of standard errors clustered at country-year level are in parentheses. ${ }^{* *}, * *$, and $*$ represent a level of significance lower than $1 \%, 5 \%$, and $10 \%$, respectively. 
Table 1: Variable Definitions

\begin{tabular}{|c|c|c|}
\hline Abbreviation & Variable & Definition \\
\hline \multicolumn{3}{|l|}{ Investment } \\
\hline $\operatorname{Inv} v_{i, t}$ & Investment & $\begin{array}{l}\text { Capital expenditures of the year } t \text { over total assets at the beginning } \\
\text { of period }(t-1) \text {. }\end{array}$ \\
\hline \multicolumn{3}{|c|}{ Hypothesis explanatory } \\
\hline Cashflow $i, t$ & Cash flow & $\begin{array}{l}\text { Cash flow income based of the year } t \text { over total assets at the } \\
\text { beginning of period }(t-1)\end{array}$ \\
\hline Boone & $\begin{array}{l}\text { Country's bank } \\
\text { competition indicator }\end{array}$ & Boone indicator obtained from the World Bank open data \\
\hline Bankcon & Bank concentration & Five-bank asset concentration estimated from Bankscope data set \\
\hline Mkogdp & $\begin{array}{l}\text { Capital market } \\
\text { development }\end{array}$ & $\begin{array}{l}\text { Stock market capitalization over GDP obtained from the World } \\
\text { Bank open data }\end{array}$ \\
\hline \multicolumn{3}{|r|}{ 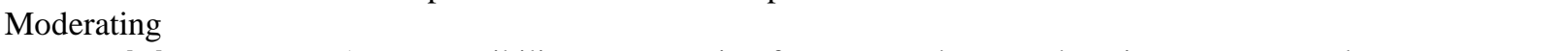 } \\
\hline Tangibility & Assets tangibility & Ratio of property, plants, and equipment over total assets \\
\hline Medtangf & $\begin{array}{l}\text { dummy firm-country } \\
\text { asset tangibility }\end{array}$ & $\begin{array}{l}1 \text { if firm tangibility is over the year-country median (unrestricted), } \\
\text { and zero otherwise (opaque) }\end{array}$ \\
\hline Ustang & $\begin{array}{l}\text { dummy US's industry } \\
\text { assets tangibility }\end{array}$ & $\begin{array}{l}1 \text { if SIC2 US's industry level's median of the tangibility ratio is } \\
\text { over the median, and zero otherwise }\end{array}$ \\
\hline Medsize & Dummy size & $\begin{array}{l}1 \text { if firm size is over the year-country median (unrestricted), and } \\
\text { zero otherwise (restricted) }\end{array}$ \\
\hline \multicolumn{3}{|r|}{ (2) } \\
\hline Qtob & Tobin's Q & $\begin{array}{l}\text { (Market capitalization }+ \text { Total debt)/Total asset's replacement } \\
\text { value }\end{array}$ \\
\hline P1 & Cash flow rights & Cash flow rights of the main shareholder \\
\hline Size & Size & Natural logarithm of total assets \\
\hline Lev & Debt ratio & Total debt to total assets \\
\hline Longdebt & Long-term debt & Long-term debt to total debt \\
\hline Cash & Cash ratio & Cash and equivalents over total assets \\
\hline Sales & Sales ratio & Net sales to total assets \\
\hline CrisisA & Asian Crisis Episode & 1 for 1999 , and zero otherwise. \\
\hline CrisisF & Global Financial Crisis & 1 for 2008 and 2009 , and zero otherwise. \\
\hline \multicolumn{3}{|c|}{ Year-country, industry } \\
\hline Year-country & $\begin{array}{l}\text { Year-country fixed } \\
\text { effects }\end{array}$ & Set of year-country dummies \\
\hline SIC2 & Industrial code & Set of SIC two-level digits industrial dummies \\
\hline
\end{tabular}


Table 2: Descriptive statistics across countries

\begin{tabular}{|c|c|c|c|c|c|c|c|c|c|c|c|c|c|c|}
\hline \multirow[b]{2}{*}{ Variables } & \multicolumn{2}{|c|}{ Argentina } & \multicolumn{2}{|c|}{ Brazil } & \multicolumn{2}{|c|}{ Chile } & \multicolumn{2}{|c|}{ Colombia } & \multicolumn{2}{|c|}{ Mexico } & \multicolumn{2}{|c|}{ Peru } & \multicolumn{2}{|c|}{ Total } \\
\hline & Mean & $\begin{array}{l}\text { Std. } \\
\text { Dev }\end{array}$ & Mean & Std. Dev & Mean & Std. Dev & Mean & $\begin{array}{l}\text { Std. } \\
\text { Dev }\end{array}$ & Mean & $\begin{array}{l}\text { Std. } \\
\text { Dev }\end{array}$ & Mean & Std. Dev & Mean & Std. Dev \\
\hline Boone & 0.052 & 0.075 & 0.163 & 0.014 & 0.038 & 0.033 & 0.065 & 0.010 & 0.027 & 0.027 & 0.048 & 0.014 & 0.074 & 0.064 \\
\hline Bankcon & 0.550 & 0.038 & 0.677 & 0.070 & 0.700 & 0.052 & 0.835 & 0.114 & 0.722 & 0.062 & 0.903 & 0.043 & 0.715 & 0.097 \\
\hline$M k o g d p$ & 0.217 & 0.171 & 0.587 & 0.186 & 1.058 & 0.242 & 0.533 & 0.176 & 0.324 & 0.095 & 0.576 & 0.196 & 0.673 & 0.353 \\
\hline $\operatorname{In} v_{i, t}$ & 0.052 & 0.055 & 0.080 & 0.075 & 0.065 & 0.057 & 0.058 & 0.063 & 0.057 & 0.057 & 0.074 & 0.064 & 0.068 & 0.064 \\
\hline Cashflow $_{i, t}$ & 0.083 & 0.067 & 0.111 & 0.088 & 0.101 & 0.076 & 0.097 & 0.101 & 0.089 & 0.075 & 0.141 & 0.095 & 0.105 & 0.083 \\
\hline$q t o b_{i, c, t}$ & 0.887 & 0.364 & 1.263 & 0.777 & 1.228 & 0.592 & 1.293 & 0.801 & 1.217 & 0.571 & 1.280 & 0.884 & 1.228 & 0.683 \\
\hline$P 1_{i, c, t}$ & 0.271 & 0.309 & 0.239 & 0.205 & 0.418 & 0.207 & 0.363 & 0.283 & 0.224 & 0.239 & 0.293 & 0.281 & 0.306 & 0.244 \\
\hline Size $_{i, c, t}$ & 19.836 & 1.343 & 20.97 & 1.616 & 20.024 & 1.673 & 21.604 & 1.439 & 21.043 & 1.464 & 19.62 & 1.323 & 20.497 & 1.664 \\
\hline$L e v_{i, c, t}$ & 0.266 & 0.172 & 0.281 & 0.158 & 0.251 & 0.136 & 0.167 & 0.125 & 0.241 & 0.155 & 0.214 & 0.144 & 0.253 & 0.151 \\
\hline Ltermde $t_{i, c, t}$ & 0.533 & 0.335 & 0.609 & 0.280 & 0.637 & 0.292 & 0.605 & 0.333 & 0.656 & 0.322 & 0.505 & 0.308 & 0.614 & 0.303 \\
\hline $\operatorname{Cash}_{i, c, t}$ & 0.072 & 0.059 & 0.150 & 0.112 & 0.063 & 0.074 & 0.087 & 0.078 & 0.087 & 0.070 & 0.076 & 0.092 & 0.095 & 0.095 \\
\hline Sales $_{i, c, t}$ & 0.777 & 0.532 & 0.741 & 0.449 & 0.672 & 0.424 & 0.467 & 0.294 & 0.784 & 0.377 & 0.709 & 0.396 & 0.718 & 0.426 \\
\hline Tangibility & 0.559 & 0.292 & 0.363 & 0.228 & 0.512 & 0.213 & 0.406 & 0.147 & 0.434 & 0.217 & 0.461 & 0.233 & 0.447 & 0.232 \\
\hline Obs. & 149 & & 941 & & 1,006 & & 92 & & 651 & & 342 & & 3,181 & \\
\hline
\end{tabular}

Notes: Data are from Thomson One, Compustat Global, and the World Bank. Variables are defined in Table 1. 
Table 3: Pearson's Correlations Matrix

\begin{tabular}{|c|c|c|c|c|c|c|c|c|c|c|c|c|}
\hline Variables & $\operatorname{In} v_{i, t}$ & Cashflow $_{i}$ & $q_{t o b} b_{i, c, t}$ & $P 1_{i, c, t}$ & $\operatorname{Size}_{i, c, t}$ & $L e v_{i, c, t}$ & Ltermdebt & $\operatorname{Cash}_{i, c, t}$ & Sales $_{i, c, t}$ & Tang. & Boone & Bankcon \\
\hline Cashflow $_{i, t}$ & $0.331^{* * *}$ & & & & & & & & & & & \\
\hline$q t o b_{i, c, t}$ & $0.218^{* * *}$ & $0.482^{* * *}$ & & & & & & & & & & \\
\hline$P 1_{i, c, t}$ & $0.038^{* * *}$ & $0.034^{*}$ & $0.145^{* * *}$ & & & & & & & & & \\
\hline $\operatorname{Size}_{i, c, t}$ & $0.052^{* * *}$ & -0.022 & $0.0412^{* *}$ & -0.0135 & & & & & & & & \\
\hline$L e v_{i, c, t}$ & $0.078^{* * *}$ & $-0.276^{* * *}$ & $-0.073^{\text {*** }}$ & -0.026 & $0.291^{* * *}$ & & & & & & & \\
\hline Ltermdebt $_{i, c}$ & ${ }_{t} 0.122^{* * * *}$ & $-0.065^{* * *}$ & -0.007 & $0.062^{* * *}$ & $0.423^{* * * *}$ & $0.394^{* * *}$ & & & & & & \\
\hline $\operatorname{Cash}_{i, c, t}$ & $0.109^{* * *}$ & $0.228^{* * *}$ & $0.197^{* * *}$ & $-0.106^{* * *}$ & $0.095^{* * *}$ & $-0.085^{* * *}$ & $-0.064^{* * *}$ & & & & & \\
\hline Sales $_{i, c, t}$ & $0.060^{* * * *}$ & $0.191^{* * *}$ & $0.132^{* * * *}$ & $-0.055^{* * *}$ & $-0.185^{* * *}$ & $-0.084^{* * *}$ & $-0.193^{* * *}$ & $0.115^{* * *}$ & & & & \\
\hline Tangibility & $0.151^{* * * *}$ & $0.010^{* * *}$ & $-0.111^{\text {*** }}$ & $0.155^{* * *}$ & 0.0001 & $0.073^{* * *}$ & $0.190^{* * *}$ & $-0.376^{\text {*** }}$ & $-0.218^{* * *}$ & & & \\
\hline Boone & $0.127^{* * * *}$ & $0.108^{* * *}$ & 0.0273 & $-0.166^{* * *}$ & $0.101^{* * *}$ & $0.071^{* * *}$ & $-0.049^{* * *}$ & $0.324^{* * *}$ & $0.044^{* *}$ & $-0.179^{* * *}$ & & \\
\hline Bankcon & 0.0029 & $0.086^{* * *}$ & $0.089^{* * *}$ & $0.039^{* *}$ & -0.017 & $-0.082^{* * *}$ & -0.022 & $-0.077^{* * *}$ & -0.027 & -0.009 & $-0.247^{* * *}$ & \\
\hline Mkogdp & $0.050^{* * *}$ & $0.106^{* * *}$ & $0.131^{* * *}$ & $0.309^{* * *}$ & $-0.125^{\text {*** }}$ & -0.0113 & $0.068^{* * *}$ & $-0.095^{* * *}$ & $-0.069^{* * *}$ & $0.098^{* * *}$ & $-0.180^{* * *}$ & $0.075^{\text {*** }}$ \\
\hline
\end{tabular}

Notes: Variables are defined in Table 1. ***,**, and * represent a level of significance lower than $1 \%, 5 \%$, and $10 \%$, respectively. 
Table 4. Bank Competition and Financial Constraints: Generalized Method of Moments

\begin{tabular}{|c|c|c|c|}
\hline Variables & $\begin{array}{c}\text { Total } \\
(1) \\
\end{array}$ & $\begin{array}{c}\text { Total } \\
(2) \\
\end{array}$ & $\begin{array}{c}\text { Surviving Firms } \\
\text { (3) }\end{array}$ \\
\hline $\operatorname{In} v_{i, t-1}$ & $\begin{array}{l}0.578^{* * *} \\
(4.697)\end{array}$ & $\begin{array}{l}0.531^{* * *} \\
(4.301)\end{array}$ & $\begin{array}{l}0.602^{* * *} \\
(3.376)\end{array}$ \\
\hline $\operatorname{Cashflow}_{i, t}$ & $\begin{array}{l}0.038^{* *} \\
(1.973)\end{array}$ & $\begin{array}{l}0.055^{* * *} \\
(2.599)\end{array}$ & $\begin{array}{l}0.056^{* * * *} \\
(2.634)\end{array}$ \\
\hline Cashflow $_{i, c, t} *$ Boone $_{c, t}$ & $\begin{array}{l}0.750^{* *} \\
(2.346)\end{array}$ & $\begin{array}{l}0.805^{* *} \\
(2.540)\end{array}$ & $\begin{array}{l}0.705^{* *} \\
(2.301)\end{array}$ \\
\hline Qtob & $\begin{array}{l}0.010^{* * *} \\
(2.682)\end{array}$ & $\begin{array}{l}0.013^{* * *} \\
(3.260)\end{array}$ & $\begin{array}{c}0.008^{*} \\
(1.721)\end{array}$ \\
\hline $\mathrm{P} 1$ & & $\begin{array}{c}0.002 \\
(0.131)\end{array}$ & $\begin{array}{c}0.010 \\
(0.670)\end{array}$ \\
\hline Size & & $\begin{array}{l}-0.000 \\
(-0.012)\end{array}$ & $\begin{array}{c}0.000 \\
(0.140)\end{array}$ \\
\hline Lev & & $\begin{array}{l}0.051^{* *} \\
(2.220)\end{array}$ & $\begin{array}{l}0.056^{* *} \\
(2.225)\end{array}$ \\
\hline Longdebt & & $\begin{array}{l}-0.000 \\
(-0.030)\end{array}$ & $\begin{array}{l}-0.009 \\
(-1.077)\end{array}$ \\
\hline Cash & & $\begin{array}{l}-0.069^{* *} \\
(-2.205)\end{array}$ & $\begin{array}{c}-0.070^{*} \\
(-1.874)\end{array}$ \\
\hline Sales & & $\begin{array}{c}0.002 \\
(0.313)\end{array}$ & $\begin{array}{c}-0.002 \\
(-0.302)\end{array}$ \\
\hline- & & & \\
\hline Observations & 2,982 & 2,982 & 2,587 \\
\hline Number of ID & 423 & 423 & 335 \\
\hline Country-year FE & Yes & Yes & Yes \\
\hline F-Test & 10.230 & 7.169 & 8.122 \\
\hline Auto(1) & $3.31 \mathrm{e}-05$ & $5.96 \mathrm{e}-05$ & 0.00100 \\
\hline Auto(2) & 0.351 & 0.349 & 0.325 \\
\hline Hansen $p$-value & 0.416 & 0.395 & 0.507 \\
\hline Marg. effect & $\begin{array}{l}0.093^{* * *} \\
(5.88)\end{array}$ & $\begin{array}{l}0.114^{* * *} \\
(6.12)\end{array}$ & $\begin{array}{l}0.107^{* * *} \\
(5.44)\end{array}$ \\
\hline
\end{tabular}

Notes: Inv $v_{i, t}$ is capital expenditures scaled by lagged total assets. Cashflow C $_{i, t}$ is the income-based cash flow over lagged total assets. Boone ${ }_{c, t}$ represents the Boone indicator as a proxy of bank competition. Qtob, P1, Size, Lev, Longdebt, Cash and sales are control variables defined in Table 1. $f_{i}$ is the firm-specific effect, $y c_{t}$ denotes the yearcountry dummies, and $u_{i, t}$ represents the individual error term. Auto(2) is a test of second-order serial autocorrelation of the residuals under the null hypothesis of no serial correlation. The Hansen test is a test of overidentifying restrictions, asymptotically distributed as $\chi^{2}$ under the null hypothesis of no correlation between the instruments and the error term. $t$-statistics of standard errors clustered at country-year level are in parentheses. ***, **, and * represent a level of significance lower than $1 \%, 5 \%$, and $10 \%$, respectively. 
Table 5. Bank Competition, Capital Markets Development and the Financial Constraints: Generalized Method of Moments

\begin{tabular}{|c|c|c|c|}
\hline Variables & $\begin{array}{c}(1) \\
\text { Total }\end{array}$ & $\begin{array}{c}(2) \\
\text { Total }\end{array}$ & $\begin{array}{c}\text { (3) } \\
\text { Surviving Firms }\end{array}$ \\
\hline$\overline{I n v_{i, t-1}}$ & $0.581^{* * *}$ & $0.545^{* * *}$ & $0.565^{* * *}$ \\
\hline & $(5.175)$ & $(5.042)$ & $(4.587)$ \\
\hline Cashflow $_{i, t}$ & 0.082 & $0.097^{*}$ & $0.094^{*}$ \\
\hline & $(1.640)$ & $(1.938)$ & $(1.817)$ \\
\hline Cashflow $_{i, c, t} *$ Boone $_{c, t}$ & $0.683^{* *}$ & $0.710^{* *}$ & $0.689^{* * *}$ \\
\hline & $(2.186)$ & $(1.972)$ & $(2.042)$ \\
\hline $\operatorname{Cashflow}_{i, c, t} * \operatorname{Mkogdp}_{c, t}$ & $\begin{array}{l}-0.059 \\
(-1.068)\end{array}$ & $\begin{array}{l}-0.055 \\
(-0.924)\end{array}$ & $\begin{array}{l}-0.057 \\
(-1.036)\end{array}$ \\
\hline Qtob & & $\begin{array}{l}0.011^{* *} \\
(2.548)\end{array}$ & $\begin{array}{c}0.008^{*} \\
(1.905)\end{array}$ \\
\hline $\mathrm{P} 1$ & & $\begin{array}{c}0.003 \\
(0.240)\end{array}$ & $\begin{array}{c}0.005 \\
(0.423)\end{array}$ \\
\hline Size & & $\begin{array}{c}0.000 \\
(0.016)\end{array}$ & $\begin{array}{c}0.002 \\
(0.787)\end{array}$ \\
\hline Lev & & $\begin{array}{l}0.045^{* * *} \\
(2.196)\end{array}$ & $\begin{array}{c}0.034 \\
(1.527)\end{array}$ \\
\hline Longdebt & & $\begin{array}{l}-0.001 \\
(-0.115)\end{array}$ & $\begin{array}{l}-0.000 \\
(-0.050)\end{array}$ \\
\hline Cash & & $\begin{array}{l}-0.069^{* *} \\
(-2.245)\end{array}$ & $\begin{array}{l}-0.059^{*} \\
(-1.849)\end{array}$ \\
\hline Sales & & $\begin{array}{c}0.002 \\
(0.425)\end{array}$ & $\begin{array}{c}-0.002 \\
(-0.201)\end{array}$ \\
\hline Observations & 2,982 & 2,982 & 2,587 \\
\hline Number of ID & 423 & 423 & 335 \\
\hline Country-Year FE & Yes & Yes & Yes \\
\hline F-Test & 9.973 & 7.760 & 6.179 \\
\hline Auto(1) & $1.82 \mathrm{e}-05$ & $2.20 \mathrm{e}-05$ & 0.000125 \\
\hline Auto(2) & 0.449 & 0.438 & 0.574 \\
\hline Hansen $p$-value & 0.492 & 0.361 & 0.498 \\
\hline Marg. effect $($ Crisis $=0)$ & $\begin{array}{l}0.093^{* * *} \\
(5.47)\end{array}$ & $\begin{array}{l}0.113^{* * *} \\
(5.93)\end{array}$ & $\begin{array}{l}0.107^{\text {**** }} \\
(5.49)\end{array}$ \\
\hline
\end{tabular}

Notes: Inv $v_{i, t}$ is capital expenditures scaled by lagged total assets. Cashflow C $_{i, t}$ is the income-based cash flow over lagged total assets. Boone $c_{c, t}$ represents the Boone indicator as a proxy of bank competition. Mkogdp $p_{c, t}$ is the stock market capitalization over GDP and represents the capital market development proxy. Qtob, P1, Size, Lev, Longdebt, Cash and sales are control variables defined in Table $1 . f_{i}$ is the firm-specific effect, $\mathrm{yc}_{\mathrm{t}}$ denotes the year-country dummies, and $u_{i, t}$ represents the individual error term. Auto(2) is a test of second-order serial autocorrelation of the residuals under the null hypothesis of no serial correlation. The Hansen test is a test of overidentifying restrictions, asymptotically distributed as $\chi^{2}$ under the null hypothesis of no correlation between the instruments and the error term. The $t$-statistics of standard errors clustered at country-year level are in parentheses. ***,**, and * represent a level of significance lower than $1 \%, 5 \%$, and $10 \%$, respectively. 
Table6. Bank Competition and Financial Constraints (Subsamples): Generalized Method of Moments

\begin{tabular}{|c|c|c|c|c|}
\hline Variables & $\begin{array}{c}\text { (1) } \\
\text { US' Tang. Low }\end{array}$ & $\begin{array}{c}\text { (2) } \\
\text { US' Tang. High }\end{array}$ & $\begin{array}{c}\text { (3) } \\
\text { Size: Low }\end{array}$ & $\begin{array}{c}\text { (4) } \\
\text { Size: High }\end{array}$ \\
\hline \multirow[t]{2}{*}{$\overline{I n v_{i, t-1}}$} & $0.593^{* * *}$ & $0.472^{* * *}$ & $0.438^{* * *}$ & $0.799^{* * *}$ \\
\hline & $(6.041)$ & $(3.181)$ & $(2.633)$ & $(4.770)$ \\
\hline \multirow[t]{2}{*}{ Cashflow $_{i, t}$} & $0.127^{* * *}$ & -0.010 & $0.068^{* *}$ & -0.022 \\
\hline & $(3.555)$ & $(-0.282)$ & $(2.573)$ & $(-0.292)$ \\
\hline \multirow[t]{2}{*}{ Cashflow $_{i, c, t} *$ Boone $_{c, t}$} & $0.541^{*}$ & $1.391^{* * * *}$ & $0.985^{\text {*** }}$ & 0.696 \\
\hline & $(1.655)$ & $(2.613)$ & $(2.636)$ & $(0.931)$ \\
\hline \multirow[t]{2}{*}{ Qtob } & $0.007^{* *}$ & $0.014^{*}$ & 0.003 & $0.012^{*}$ \\
\hline & $(2.166)$ & $(1.844)$ & $(0.705)$ & (1.739) \\
\hline \multirow[t]{2}{*}{$\mathrm{P} 1$} & 0.020 & -0.006 & 0.004 & 0.019 \\
\hline & (1.313) & $(-0.274)$ & $(0.253)$ & $(0.789)$ \\
\hline \multirow[t]{2}{*}{ Size } & -0.002 & -0.005 & $0.008^{* *}$ & -0.004 \\
\hline & $(-0.882)$ & $(-1.119)$ & $(2.405)$ & $(-0.752)$ \\
\hline \multirow[t]{2}{*}{ Lev } & $0.079^{* * * *}$ & 0.049 & $0.059^{*}$ & 0.011 \\
\hline & $(2.882)$ & $(1.423)$ & (1.734) & $(0.288)$ \\
\hline \multirow[t]{2}{*}{ Longdebt } & $0.021^{* *}$ & -0.019 & -0.004 & 0.008 \\
\hline & $(2.151)$ & $(-1.419)$ & $(-0.487)$ & $(0.644)$ \\
\hline \multirow[t]{2}{*}{ Cash } & $-0.070^{* *}$ & -0.047 & $-0.109^{* * * *}$ & -0.030 \\
\hline & $(-2.048)$ & $(-0.899)$ & $(-2.703)$ & $(-0.647)$ \\
\hline \multirow[t]{2}{*}{ Sales } & -0.015 & 0.004 & $0.019^{* *}$ & -0.007 \\
\hline & $(-1.496)$ & $(0.509)$ & $(2.037)$ & $(-0.871)$ \\
\hline Observations & 1,627 & 1,355 & 1,815 & 1,167 \\
\hline Number of ID & 229 & 194 & 270 & 153 \\
\hline Country-Year FE & Yes & Yes & Yes & Yes \\
\hline F-Test & 14.01 & 13.80 & 10.84 & 8.776 \\
\hline Auto(1) & 0.000487 & 0.00346 & 0.00397 & 0.00291 \\
\hline Auto(2) & 0.333 & 0.888 & 0.994 & 0.214 \\
\hline Hansen $p$-value & 0.628 & 0.688 & 0.620 & 0.735 \\
\hline \multirow[t]{2}{*}{ Marg. effects $($ Crisis $=0)$} & $0.166^{* * *}$ & $0.093^{* * *}$ & $0.140^{* * *}$ & $0.029^{* * *}$ \\
\hline & $(4.70)$ & $(3.53)$ & $(8.17)$ & $(0.42)$ \\
\hline \multicolumn{5}{|l|}{$t$-statistic } \\
\hline Diff. on Joint Sig. (2)-(1) & & $-64.54^{* * *}$ & & \\
\hline Diff. on Joint Sig. (4)-(3) & & & & $-53.86^{* * *}$ \\
\hline
\end{tabular}

Notes: Inv $v_{i, t}$ is capital expenditures scaled by lagged total assets. Cashflow $w_{i, t}$ is the income-based cash flow over lagged total assets. Boone ${ }_{c, t}$ represents the Boone indicator as a proxy of bank competition. Qtob, P1, Size, Lev, Longdebt, Cash and sales are control variables defined in Table 1. $f_{i}$ is the firm-specific effect, $y c_{t}$ denotes the yearcountry dummies, and $u_{i, t}$ represents the individual error term. Auto(2) is a test of second-order serial autocorrelation of the residuals under the null hypothesis of no serial correlation. The Hansen test is a test of overidentifying restrictions, asymptotically distributed as $\chi^{2}$ under the null hypothesis of no correlation between the instruments and the error term. $t$-statistics of standard errors clustered at country-year level are in parentheses. ***, **, and * represents a level of significance lower than $1 \%, 5 \%$, and $10 \%$, respectively. 
Table 7. Crisis, Bank Competition and Financial Constraints: Generalized Method of Moments

(1) (3)

Great Argentinean

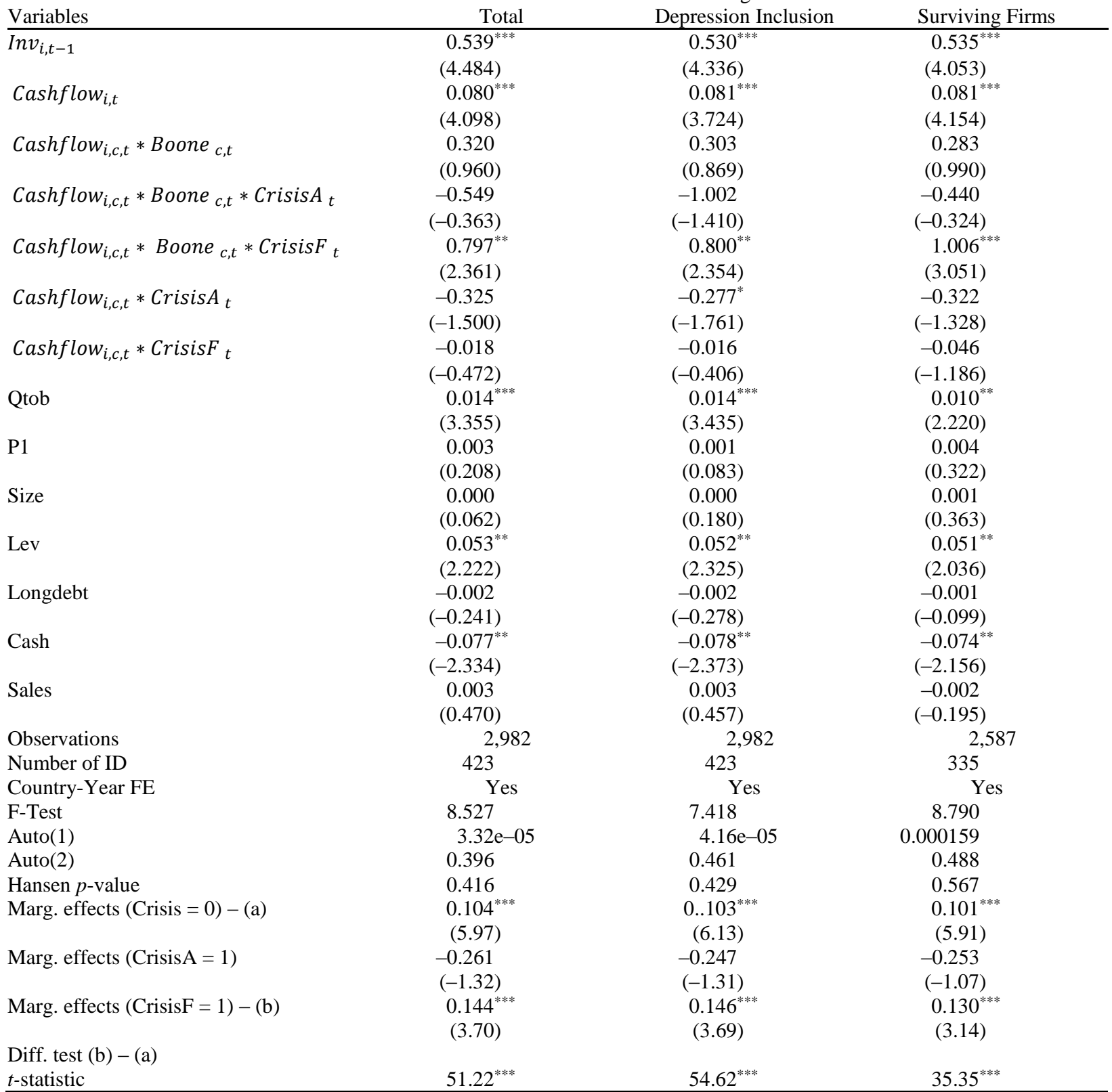

Notes: $\operatorname{Inv}_{i, t}$ is capital expenditures scaled by lagged total assets. Cashflow ${ }_{i, t}$ is the income-based cash flow over lagged total assets. Boone $e_{c, t}$ represents the Boone indicator as a proxy of bank competition. Crisis $A_{t}$ is a dummy variable that equals 1 for 1999 in column 1 and in column 2 also takes the value of 1 for Argentina in the period 2000-2002. Crisis $F_{t}$ is a dummy variable that equals 1 for 2007 and 2008. Qtob, P1, Size, Lev, Longdebt, Cash and sales are control variables defined in Table 1. $f_{i}$ is the firm-specific effect, $y c_{t}$ denotes the year-country dummies, and $u_{i, t}$ represents the individual error term. Auto(2) is a test of second-order serial autocorrelation of the residuals under the null hypothesis of no serial correlation. The Hansen test is a test of overidentifying restrictions, asymptotically distributed as $\chi^{2}$ under the null hypothesis of no correlation between the instruments and the error term. $t$-statistics of standard errors clustered at country-year level are in parentheses. $* * *, * *$, and $*$ represents a level of significance lower than $1 \%, 5 \%$, and $10 \%$, respectively. 